\title{
人工肛門管理における吸引式洗腸器の有用性について
}

\author{
千葉大学医学部第 1 外科

$\begin{array}{lllll}\text { 更科 } & \text { 広串 } & \text { 斉藤 } & \text { 典男 新井 竜夫 } \\ \text { 布村 } & \text { 正夫 } & \text { 奥井 } & \text { 勝二 }\end{array}$ \\ 同 手術部 \\ 桶口道雄古山信 明 \\ 筑波大学臨床医学系外科 \\ 深尾 立 折居 和雄 岩崎 洋治
}

\section{EFFECTIVE COLOSTOMY IRRIGATION USING A NEW DEVISED APPLIANCE}

\author{
Hiromi SARASHINA, Norio SAITOH, Tatsuo ARAI, \\ Masao NUNOMURA and Katsuji OKUI
}

The first department of surgery, Chiba university school of medicine

Michio HIGUCHI and Nobuaki FURUYAMA

Operating theatre, Chiba university hospital

Katashi FUKAO, Kazuo ORII and Yoji IWASAKI

Institute of clinical medicine, the university of Tsukuba

新しく開発した吸引式洗腸器の有用性を知る目的で, 従来より使用されていたストッパー式洗腸器 と比較検討した，対象はMiles 手術後の結腸終端人工肛門保有者で，それぞれの洗腸器を使用してい た15症例 (計30症例) について対面調查を行った。 その結果, 吸引式洗腸器の長所としては穿孔の危 険が少いこと, 速やかに完全な洗腸が行えること, 臭気もなく清潔に行えることが挙げられた。一方, ストッパー式洗腸器に比べ十分な指導を必要とするなど，いくつかの短所も示唆された.

以上の結果から, 本洗腸器は若い知識人に適しており, さらに狭窄様人工肛門症例の洗腸にむ威力 を発揮していることが明らかとなった。

策引用語：人工肛門洗腸，ストーマリハピリテーション

I.はじめに

人工肛門からの注腸 X 線検査に際し, バリウムや空 気の逆流を防ぐ目的で，著者らはこれまで人工肛門注 腸補助器を開発しその有用性を報告してきた ${ }^{112)}$. この 補助器の特徴は人工肛門周囲を污すことなく, 腸穿孔 の心配が全くないことである。

このよらな X 線検査を受けた人々が，「検査後 2 日 間も排便がなく，大変快適であった」といら情報にヒ ントを得て, 本補助器を改良して新型吸引式洗腸器を 考案した。これまでにこの洗腸器を臨床的に広く応用

$<1985$ 年 7 月 10 日受理 $>$ 別刷請求先：更科 広実 ₹280 千葉市亥鼻 $1-8-1$ 千葉大学医学部第 1 外科
してきたが，その有用性を知る目的で，従来より使用 されていたストッパー式洗腸器と比較し, その長所・ 短所について検討したので報告する。

\section{II. 新型洗腸器への改良と使用法}

人工肛門注腸補助器は, 図 1 に示すごとく内外 2 筒 のプラスチック製のもので，外筒部を陰圧にすること により人工肛門周囲皮膚に固定し，逆流を防止するこ とが出来るるのである. 新型吸引式洗腸器のための改 良点は，図 2 に示すごとくまず洗腸液の注入孔を本体 の側方に造り，本体の底部はくり抜き，ここにビニー ル製の円筒（図 2-4）をとりつけられるようにし，排 便を円滑に流せるように工夫した，更にゴム製のベル 卜（図 2-7）でこの本体を人工肛門部に固定し，洗腸 
図 1 人工肛門注腸補助器

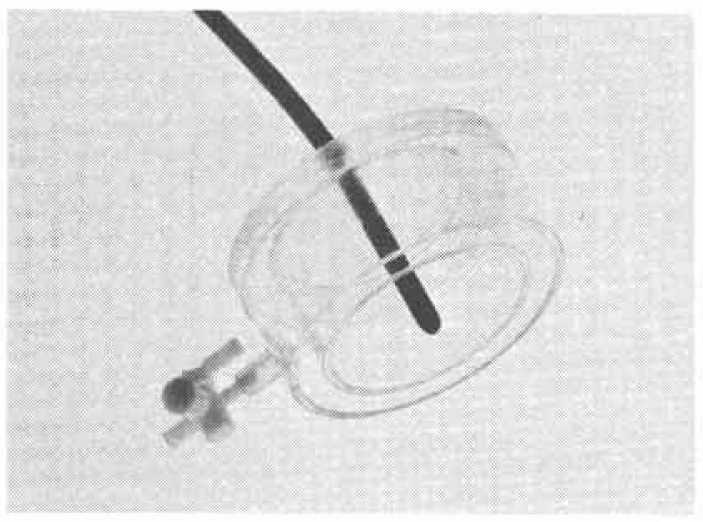

図 2 吸引式洗腸器の部品

1. ゴム球，2．本体，3，釷子，4.ビニール袋，

5. ベルトかけ，6. キャップ，7。 ベルト(ゴム製)

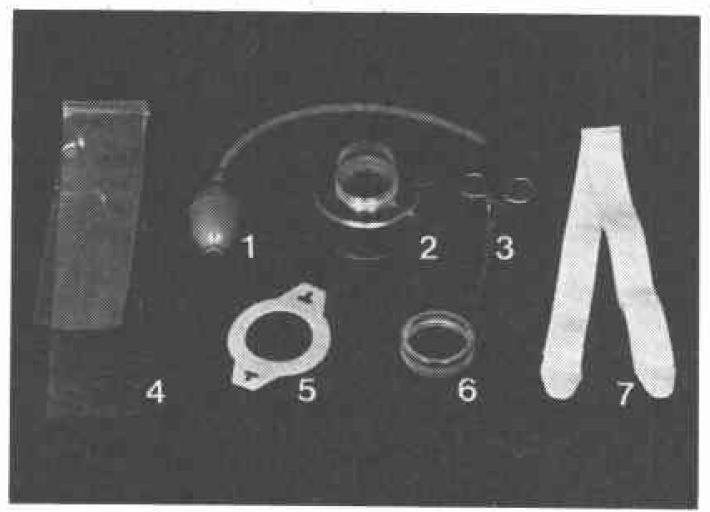

器のズレを無くするようにした。な幏庭での使用が 中心となるため，外筒部を陰王にするための特別なゴ ム球（図 2-1）を用意した。

その使用法は図3に示すような部品の組み立てから 始まる.まずビニール袋を洗腸器本体底部の突出して いる部分にかぶせ，ベルトかけ（図 2-5)とキャップ （図 2-6）をこの上にはめてねじ込む.つぎにビニー ル袋を本体に近い部分で念り，この部分から水が漏れ ないように鉗子で強く閉める、ゴム球を吸引孔にさし 达み, ベルトをベルトかけに装着する. 以上でこの洗 腸器の組み立てが終了する(図 3).これらの操作で大 切な点は, ビニール袋を確実に本体にはめ込み, ここ から水が漏れないようにすることである、本洗腸器の 原理を図 4 に示す。

次に実際の使用方法をその操作手順に従い列記する (図 5-A, B).
図 3 吸引式洗腸器の組み立て

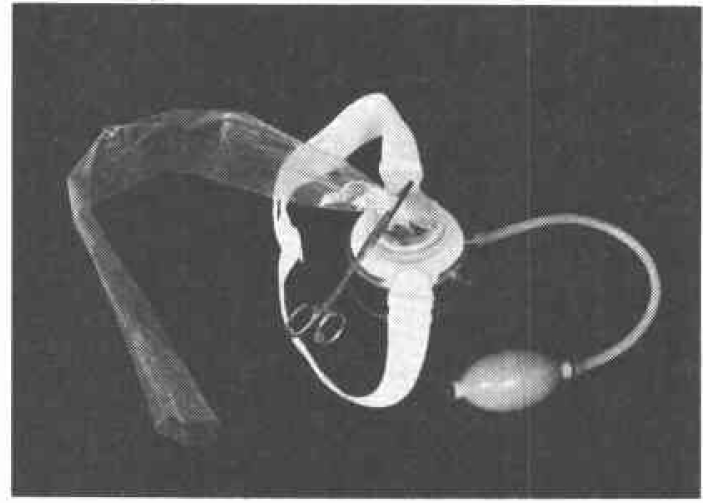

図 4 吸引式洗腸器の原理

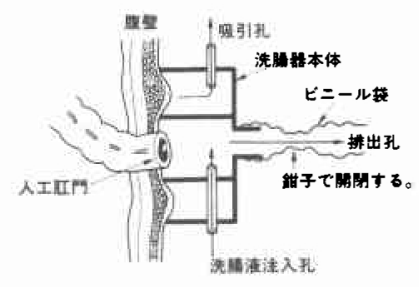

(1) 組み立ての完了した洗腸器本体を,ストーマがそ の内心円の中心にくるように腹部に当てる.

(2) ペルトを背部から廻し, 本体に固定し, これがず れたり動いたりしないよらにする。

(3) 微温湯約 $2 l$ 入った, イルリガートルからの チューブを注入孔に接続する。

(4) 左手で軽く本体を支持しながら, 右手で吸引用ゴ ム球を 2 ・ 3 回握り，本体が腹壁に吸い着くようにす 万.

(5) イルリガートルからのロールクランプ（図 5-A の矢印）を開き，洗腸液を注入する。

(6) 注入終了後ロールクランプを閉じる.

(7) 数分後, ビニール袋内の洗腸液が混濁してきた ら, ビニール袋の先端を便器に入れ，鉗子を開く.

(8) ゴム球を本体からはずし，吸引を解除する.

(9) 排便がすべて終了したらべルトをはずし,ビニー ル袋を付けたまま洗腸器をストーマより取り外す。

(10)ストーマのまわりを清拭後, 同部に軽くガーゼを 当てる.

以上の操作において, 洗腸を成功させるための最も 重要な点は, 常にゴム球からの陰圧がかかるようにす ることである、このためゴム球が少しでも抎張してき たら，ただちに右手で握りしめ，常に陰王がかかって 
図 5 吸引式洗腸器の使用法

$\mathrm{A}$ ：吸引状態で洗腸液を注入している（矢印はイル リガートルのロールクランプ). B ：銝子をはずし吸 引を解除している。
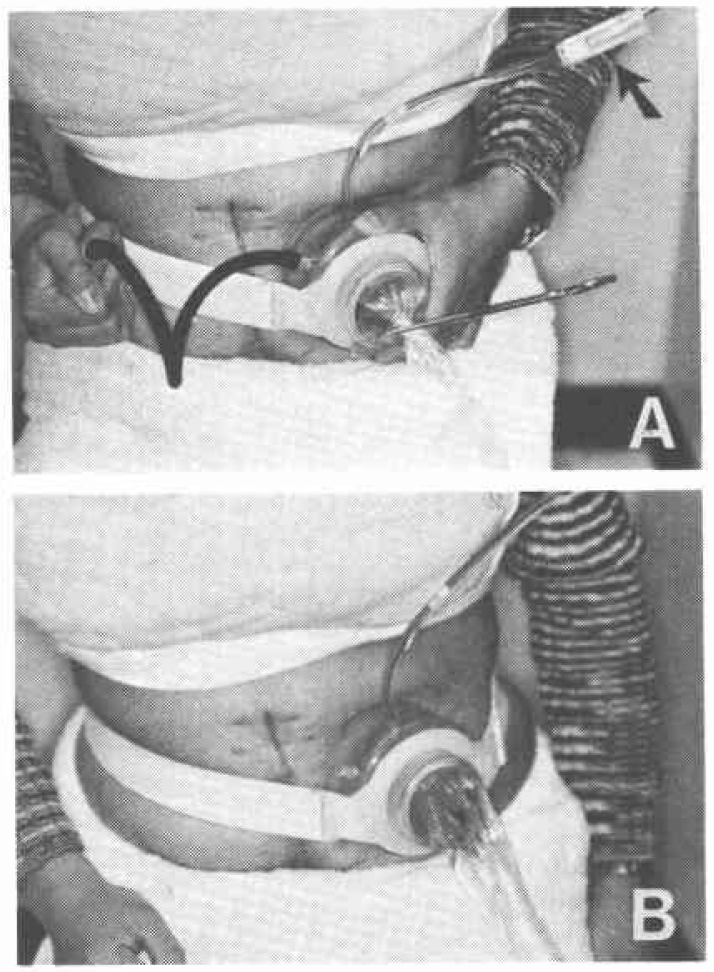

いるよらにしなければならない。

\section{III. 対象と方法}

対象とした症例は，腹会陰式直腸切断術後に $\mathrm{S}$ 状結 腸終端人工肘門の造設された 30 症例である。このうち 従来から使われてきたストッパー式洗腸器（コロク リーン，東京衛材）を使用した15名は，千葉大学医学 部第 1 外科にて手術された症例で,これをI群とした。 これに対し吸引式洗腸器（メラ・ダルムエース, 泉工 医科）を使用した15名は，筑波大学臨床医学系消化器 外科にて手術された症例で，これをII群とした。これ ら I 群とII群の各症例を外来にて個別に対面調査し， 各群の洗腸状況を比較した。な打両群の間に年龄・性 別に有意の差を認めなかった。

\section{IV, 調査結果}

1) 洗腸回数について

いゔれの群も毎日 1 回の洗腸を行っている症例が最 も多く，ついで 2 日に 1 回の症例が多かった。この点 に関して両群の間に明らかな差を認めなかった。しか
表 1 洗腸器使用状況の比較（1）

\begin{tabular}{|c|c|c|c|}
\hline \multirow{4}{*}{ 洗筫回数 } & & [ストッハージ & 〔曼引式] \\
\hline & 每 & 10 & 8 \\
\hline & 2日に1回 & 4 & 5 \\
\hline & 逗にに〜2回 & 1 & 2 \\
\hline \multirow[t]{3}{*}{ 注入做量 } & $\sim 800 \mathrm{an}$ & 13 & 1 \\
\hline & $800 \sim 1200$ & 2 & 11 \\
\hline & $1200 \sim$ & 0 & 3 \\
\hline \multirow[t]{3}{*}{ 注入時间 } & $\sim 3$ 分 & 2 & 10 \\
\hline & $3 \sim 6$ & 9 & 3 \\
\hline & $6 \sim$ & 4 & 2 \\
\hline
\end{tabular}

し後述するように, II 群では次回の排便が48時間以上 なかったと答えた症例が多く，このような症例でも 1 回/ 1 2 日の洗腸を積極的に行い,排ガスなどの臭い を予防している者が少くないことがうかがわれた。

2）注入液 (洗腸夜) 量について

この比較に拈いてI群では600 800ml, II 群では $1,000 \sim 1,200 \mathrm{ml}$ の症例が最も多く, 有意の差が認めら れた。この注入液量は当然残存結腸の容積に比例する。 しかし I, II 群とも S 状結腸口側 $1 / 3$ の部分に人口肛 門が造られているため，ここに示された液量の差は次 に述べる注入時間の差と考鼻合わせ，II群では洗腸液 がよりスムーズに注入されているためと考えられた。

3）注入時間について

上記の液量の注入時間は I 群で $3 \sim 6$ 分と答えた症 例が多く，このうち5〜6分のものが最も多かった. これに比べII群では 3 分以内に注入が完了しているる のが多かった。このためII群では時々注入時に腹部膨 満感を訴える症例るあり，このためあまり速く注入し ないように指導が必要である（表 1 ）。

4）排出口閉鎖時間について

これは洗腸液の注入後，ストーマからの排液をどの くらい長く閉鎖しているかを比較したるのである。一 般にI 群では腹満感出現や少し逆流する時期を選び, II 群ではビニール袋内の洗腸液が混濁する時期に開放 している。この時間の比較に扔いてI 群では 4 分以上 (約 $5 \sim 6$ 分)の症例が多かったのに対し, II 群では 2 ～3 分と短い時間に開放している症例が多かった。

5）排便終了までの時間について

洗腸でこの時間が最も長くかかり，洗腸者にとって は退屈に思う時間でるある。両群の比較では，I群で 最も多かったのが40分間であったのに対し，II群では 30分間の症例が最も多かった。このよ5に吸引式洗腸 器の方に洗腸時間の短縮が認められた。

6）次回排便までの時間について

洗腸後そのまま放置していた場合，次の排便が何時 間後にみられるかを調査したものである，その結果は 
表 2 洗腸器使用状況の比較 (2)

\begin{tabular}{|c|c|c|c|}
\hline \multirow{4}{*}{ 排出口阙舱時間 } & & [ストーバー式 $]$ & 【㖟引式〕 \\
\hline & $\sim 2$ 分 & 1 & 5 \\
\hline & $2 \sim 4$ & 5 & 8 \\
\hline & $4 \sim$ & 9 & 2 \\
\hline \multirow[t]{3}{*}{ 拂便維了まてひ時間 } & 30 分 & 5 & 9 \\
\hline & 40 & 8 & 5 \\
\hline & 50 & 2 & 1 \\
\hline \multirow[t]{4}{*}{ 次回排便まての時間 } & ～24時間 & 1 & 0 \\
\hline & $24 \sim 36$ & 9 & 5 \\
\hline & $36 \sim 48$ & 4 & 6 \\
\hline & $48 \sim$ & 1 & 4 \\
\hline
\end{tabular}

両群に明らかな差を認めなかったが，II群に48時間以 上排便がみられないと答光た症例が多かった.しかし， いずれの方法でも大部分の症例が，24時間以内には汪 とんど排便・排がスがないと答えていたことより，十 分な洗腸効果が得られているのが確認された（表 2).

$7 ）$ 洗腸夜の逆流や周围への污染比ついて

I 群ではストッパー周囲からの逆流のため, 周囲の 污染が時々あると答えた症例が 3 例あったのに対し， II群では吸引力のかけ方に慣れてしまえば，全く污染 がないと答えた症例が多かった。

8）人工肛門周辺の疼痛について

ストッパーを人工肛門内に挿入する時の痛みと，周 囲皮膚を吸引することによる痛みは自ずから異り比較 出来るむのではないが, アンケート式に質問してみた。 その結果, II群の中で吸引による痛及を訴えた症例は 4 例であった。これらの症例は瘦せた皮下脂肪の少い 症例に多かった。

9）洗腸後の腹部症例について

これについては両群間に明らかな差を認めなかっ た. 腹部症状としては, 腹部膨満感や軽度の腹痛が大 部分で, 症状の程度についても大略同様のものであっ た。

10）洗腸後の処理について

洗腸終了後の日常生活に招いて，人口肛門部の処置 をどのよらにしているかについて調査した，その結果 は両群とも大部分の症例がガーゼを当てているのみ で，ラパックなどの粘着性装具を使用している症例は 少なかった。 また外出時のみそのような装具をつける と答党た症例子意外に少なかった（表 3 ）.

\section{V. 両洗腸器の臨床的比較}

以上述べてきた調査結果や, 術後の洗腸指導時に得 られた経験から, 吸引式洗腸器の臨床的特徵をストッ パー式洗腸器のそれと比較した(表 4)。これにより次 のような諸点が吸引式洗腸器の長所として指摘され た.
表 3 洗腸器使用状況の比較 (3)

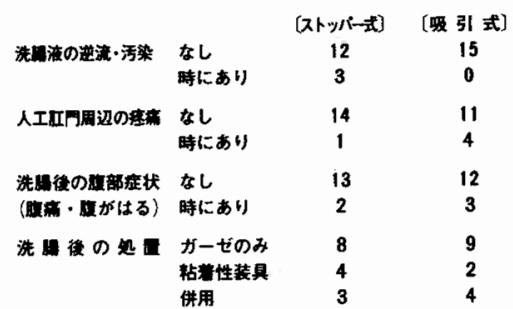

表 4 両洗腸器における有用性の比較

\begin{tabular}{|c|c|c|}
\hline & 〔ストッパー式〕 & 〔㖟引式) \\
\hline 洒 格 & 安い & 高い \\
\hline 手街から洗簢までの期的 & 㹂い & 早期より可 \\
\hline 洗的中の典気 & 有 & 笛籍 \\
\hline 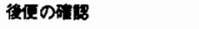 & 容畼 & 不畍なことあり \\
\hline 道する年令 & 老年者 & 青·壮年 \\
\hline 栦 力 & 不受 & 必要 \\
\hline るい & 道 & 不道 \\
\hline 指垱状況 & 頚れが早い & 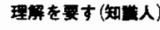 \\
\hline finger ブジー & 必要 & 不曼 \\
\hline 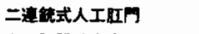 & 道 & 不流 \\
\hline 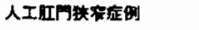 & 不造 & 箈 \\
\hline
\end{tabular}

(1)ストーマに直接触れないため術後早期 ( 5 日目以 降）より洗腸可能で，術後の排ガス促進やイレウスの 予防に役立つ。

(2) 洗腸器とビニール袋で密閉されているので洗腸 中の臭気が汪とんど無い.

(3) イルリガートルに残った液で洗腸器やビニール に残った便を洗い流すことが出来る。

(4) 周囲への漏れがないので, 注入量と排液量を比較 し洗腸の終了時を予測出来る。

(5) 洗腸前に finger プジーを必要とせず，ストーマ 内に直接器具を挡入しないので危険が少い。

(6) ストッパー式洗腸器の使用が不可能な人工肛門 㹨窄症例にも, 吸引式洗腸器で満足出来る洗腸が可能 となった。

このような長所のみられた反面, この吸引式洗腸器 の短所としては次のような点が指摘された。

(1)いまだ広く普及していないので, ストッパー式洗 腸器に比べ高価である。

(2) 洗腸の最後にみられるわずかな排液,すなわち後 便の確認が不明のことが多い，洗腸器やビニール袋で ストーマが見ずらいためと考えられる.

(3) 吸引用ゴム球を握る力が要るため, 握力の弱い 人，すなわち衰弱した人，老人，女子などでは困難な こともある。

(4) 皮下脂肪の函めて少いるい瘦患者では, 罗引部の 皮虑が密着せず周囲から漏れることもある。 
(5)やや原理が複雑なため慣れるのに十分な理解を 要し，老年者には不向きな点もある。充完全な洗腸 が出来るようになるまで数回の指導を必要とする。

(6) ストッパー式洗腸器は二連銃式人工肛門にも使 用可能であるが，吸引式洗腸器は肛門側のストーマに む洗腸液が入るため適していない，

以上の臨床的比較を総活すると, 吸引式洗腸器の特 徵としては, 短時間に多量の液による洗腸が可能で, 洗腸中に悪臭をほとんど感じない，危険が少いなどが 挙げられる。このため若い人や知識階級の人達に広く 愛用されていた。

\section{VI. 考 察}

第 37 回日本大腸肛門病学会総会（昭和 57 年11月・東 京）の特別講演“Problems around peristomal skin" に招いて, N. N. Gill (Worldwide Ostomy Center) は「外科医は自分の造った人工肛門に責任を持っべき である」と述べわれわれに深い反省を促したことは いまだ記憶に新しいところである3．本邦においても 日本大腸肛門病学会, 日本看護協会を中心に「スト一 マリハビリテーション講習会」(委員長, 安富正幸)が 毎年開かれ，専門職としての Enterostomal Therapist を養成するようになってきた。このような䞶勢に鑑み, 著者らの開発した新型洗腸器がどのような位置にある かを知るため,これまで一般に使用されていた洗腸 器4)5) と比較し, 検討したるのである.

これまで人工肛門部の管理を目的として，食事療法 による排便のコントロールや装具の開発などが行わ れ，最近では magnetic colostomyなども試みられて いるが，いずれもいまだ満足すべき結果は得られてい ない(6)7. これに比べ浣腸療法や洗腸療法は種々の問題 を含みながらも，不随意的な排便をコントロール出来 るといら面から，有効であったとする報告が多( ${ }^{819)}$. これまでの経験からして, 人工肛門保有者に洗腸療法 を指導した時, 指導後に患者の顔つきが輝き，精神的 な憂らつ状態も晴れたといら人をみるたびに，洗腸療 法の有効珄は否定出来ないものと考克られる。

一方，洗腸療法の欠点としてこれまで次のような諸 点が挙げられていた。

(1) 腸管穿孔の危険性

(2) 洗腸時間の問題

(3) 洗腸する場所（家庭内）の問題

(4) 洗腸による各種症状

(5) 洗腸される大腸粘膜の変化などに要約されよう. Gabriel は1945年に洗腸時の腸管穿孔 9 例を報告
し，そのうち 8 例が死亡していることより洗腸療法に 批判的である ${ }^{10)}$. これらはいずれる硬いチューブを使 用して技り，剖検によりストーマより $2-21 / 2$ インチ の部分で穿孔が確認されている。このことはストーマ の中に異物を挿入することがいかに危険であるかを物 語るもので, この点著者らの開発した洗腸器は, 全て ストーマ外の操作で行われるためこの点に関する心配 は全くない。

洗腸時間や洗腸場所の問題は, 患者が洗腸をやめて しまら大きな原因となっている。これを出来るだけ短 時間に，また風呂場などでる行党るように改良出来れ ば，時間の制約や家庭内のトラブルも解決されるわけ である。この点でも吸引式洗腸器は従来のものに比べ, 洗腸時間は短縮され，閉鎖式で行兄るため入浴時に 行っている症例や，早朝に風呂場で行っている症例が 多かった。

洗腸時の腹部症状として, 腹痛や腹部膨満による重 苦しさや気分不快を訴光る症例も少くない，これには 注入速度や注入量が関係しているといわれているが, これまでの調査では必ずしもそれのみが原因とはみら れず，個人差が大きいように見受けられた。委た Mazier らも述べているように, 洗腸液に塩を一さじ 入れることによりこれらの症状を大部軽減することが 出来るので，このような指導も重要と思われた ${ }^{111}$.

洗腸による大腸粘膜の変化について浦らは, 洗腸例 12例，コントロール5 例を対象に内視鏡・生検を行い 比較検討している ${ }^{12)}$. これによれば肉眼的にも組織学 的にも両群の間に明らかな差を認めなかったと述べ, 洗腸による悪影響を否定している．今回著者らの対象 とした 30 例のうち, 内視鏡検査の行われた 6 例(ストッ パー式 2 例, 吸引式 4 例) でも, 軽度の粘膜腫脹がみ られるのみで，コントロール群との間に明らかな差を 認めなかった。

以上の調查結果を総括すると，2つの洗腸器にはそ れぞれ長所・短所が認められ，人工肛門の形，患者の 年齢・体力・理解力などを考兑, 個々の症例に適した 洗腸方法を選択してゆくことが重要と考穴られた。こ の上らな洗腸法を成功させるためには，術前から患者 によく説明し，どこにどのような人工肛門を造設した ら洗腸がやりやすいかを知ることである。このために 著者らは術前に, ビニール袋を取り外した吸引式洗腸 器を患者の腹部に装着し, 立位, 坐位により洗腸器が ズレないような最も安定した場所を選び，洗腸液注入 部の中心に印をつけるようにしている。術中にこの部 
位へskin level の小さめのストーマを造るように心掛 けている。

\section{VII. おわりに}

新しく開発した吸引式洗腸器の有用性を, 従来のス トッパー式洗腸器と比較した。 その結果, 穿孔の危険 が少ないこと，洗腸時間を短縮でさること，洗腸中の 臭気が少いこと，ストーマの狭窄例にも洗腸可能であ ることなど，2・3の有用性が示唆された。

本論文の要旨は第19回, 第25回日本消化器外科学会総会 に扔いて発表した，本洗腸器の試作にあたり協力していた だいた泉工医科工業に深謝する。

\section{文 献}

1) Sarashina H, Ozaki A, Fukao K et al: A new device for barium-enema examination following colostomy: Radiology $133: 241-242,1979$

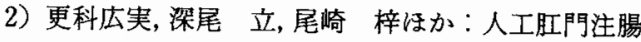
補助器の踟床的有用性について。 日消外会誌 $13: 1186-1190,1980$

3) Gill $\mathrm{NN}$ : Basic skin problems of the ostomate. 日本大腸肛門病会誌 $36: 229-233$, 1983

4) 田沢賢次, 田島健三，曾我 淳㳗加：人工肛門 after care の実際一ストーマの処理 : 局所管理か らみた治療と実際一. 臨外 32:43-49, 1977
5）牧野永城, 葛西 猛：人工肛門 after care の実際 一腸洗浄法と自然排便法一。臨外 $32: 51-55$, 1977

6) Grier WRN, Postel AH, Syarse A et al: An evaluation of colonic stoma management without irrigations. Surg Gynecol Obstet 118 : 1234-1242, 1964

7) Goligher JC, Lee PWR, Mcmahon MJ et al: The erlangen magnetic colostomy control device: technique of use and results in 22 patients. Br J Surg $64: 501-507,1977$

8）山崎靖夫, 坪井重雄, 松村功人活か：人工肛門設置 後の愁訴改善法一特に浣腸療法について一. 外科 診療 18：1041-1045, 1976

9) Macleod $\mathrm{JH}$ : Colostomy irrigation-A transatlantic controversy. Dis Col Rect 15: 357-360, 1972

10) Gabriel WB : Discussion on the management of the permanent colostomy. Proc Roy Soc Med 38 : 692-694, 1945

11) Mazier WP, Digman RD, Capehart RJ et al: Effective colostomy irrigation. Surg Gynecol Obstet $142: 905-909,1976$

12）浦 伸三, 山口敏朗, 石本喜和夫洁か：人工肛門管 理としての洗腸療法に関する臨床的検討. 日本大 腸肛門病会誌 $31 ： 201-206,1978$ 